\title{
Effect of Different Sources of Organic Manures and Decomposers on Physico-Chemical Properties of Soil under Chilli Cultivation
}

\author{
Karale Gangadhar $^{1 *}$, N. Devakumar ${ }^{1}$, P.K. Basavaraja ${ }^{2}$, K. Murali ${ }^{1}$ and B. Boraiah ${ }^{1}$ \\ Department of Agronomy, University of Agricultural Sciences, GKVK, Bengaluru-65, India \\ *Corresponding author
}

\section{A B S T R A C T}

\section{Keywords}

Organic manures,

Decomposers,

Organic carbon, $\mathrm{pH}$,

EC and bulk density

Article Info

Accepted:

10 November 2019

Available Online:

10 December 2019
Organic manures are known to be rich sources of both macro and micro nutrients of the crop. They also help in improving the physic-chemical status of the soil. In this experiment, the influences of different sources of organic manures and decomposers on the soil physical, chemical as well as biological properties of soil under chilli cultivation soils were investigated. A field experiment was conducted at research and demonstration block of Research Institute on Organic Farming (RIOF), UAS, GKVK, Bengaluru during 2017 2018. Different sources of organic manures (FYM, vermicompost, poultry manure and sheep manure) on $\mathrm{N}$ equivalent basis were incorporated into the top $20 \mathrm{~cm}$ of soil in line sowing. To determine the effect of the organic sources, the soil samples were collected 1 month after addition of organic manures from depth of $20 \mathrm{~cm}$. The soil physic-chemical properties i.e., $\mathrm{pH}, \mathrm{EC}$, bulk density, water holding capacity and organic carbon content were determined. The results showed that application of organic manures and decomposers had significant effect on soil physical and chemical properties like EC, $\mathrm{pH}$, organic carbon, bulk density and water holding capacity as compared to the control, soil treated with organic manures showed apparent increases of organic matter, EC, WHC and reduces bulk density. Irrespective of the decomposers treatments, application of vermicompost on $\mathrm{N}$ equivalent basis had recorded significantly higher physic-chemical properties viz., water holding capacity (35.49 per cent), infiltration rate $\left(7.48 \mathrm{~cm} \mathrm{hr}^{-1}\right)$, electronic conductivity $\left(0.21 \mathrm{dS} \mathrm{m}^{-1}\right)$ as compared to the other control.

\section{Introduction}

Chilli (Capsicum annuum L.) is a popular vegetable crop, commonly known as bell pepper or sweet pepper or hot pepper or chilli. It was consumed as a spice, vegetable, pickle, condiment and sauce. Internationally, chillies are consumed as a spice and become an ingredient in medicines and beverages (Daundkar and Bairagi, 2015, Velayutham and Damodaran, 2015). Green chillies provide proteins, minerals, vitamin $\mathrm{A}$ and $\mathrm{C}$ while dry chillies are known as a source of vitamin A and D (Patel, 2017). Organic matter plays an important and multi-faceted role in soil. Physically, organic matter influences soil 
structure and all associated properties. Chemically, soil organic matter affects the cation exchange capacity and the capacity for buffering changes in soil $\mathrm{pH}$. Biologically, organic matter acts as the nutrient and energy supply for microbial biomass and higher plants. A soil which is biologically and chemically fertile but which cannot physically support crop development will not fulfill its agronomic potential. Soil productivity is, therefore, determined by a combination of organic matter's influence on physical, chemical, and biological soil properties (Eilin and Kevin, 2012).

The soils physical condition directly influences environmental quality and crop production (Arshad et al., 1996). Wellaggregated soils in good physical condition maintain the balance of air and water required to promote many other soil properties (Lowery et al., 1996). Physical soil quality parameters include soil texture, bulk density, porosity, top soil depth, water holding capacity, soil temperature, and aggregate stability. Soil texture has considerable influence on moisture retention and hydraulic conductivity as well as bulk density (Arshad and Coen, 1992). Soils with a fine texture will have greater moisture retention and hydraulic conductivity and will exhibit a lower bulk density. Spain (1990) found a positive correlation between the soil texture and the amount of soil organic carbon. Soils with coarse (sand) textures tend to have a higher bulk density then soils with fine (clay) textures. Soil properties and processes such as moisture retention, water flow, root development, nutrient cycling, and the sustainability of micro and macro organisms are negatively influenced by high bulk density values (Arshad et al., 1996, Arshad and Coen, 1992).

Chemical parameters of soil have shown profound interaction with biological properties and processes in soil. Chemical parameters of soil quality include, organic carbon $\mathrm{pH}$, and electrical conductivity. Total carbon and nitrogen correlate to the amount of SOM content. The organic C-organic matter conversion factors for surface soils have varied from 1.72 to 2.0 (Nelson and Sommers, 1996). Soil organic matter is often considered the key quality factor in soil and is highly correlated to numerous factors influencing productivity and environmental sustainability (Stott and Martin, 1990). Organic matter improves soil quality by improving other properties such as nutrient and water storage, buffering capacity and microbial activity/diversity (Arshad and Coen, 1992). The present study was undertaken to study the effect of different sources of organic manures and decomposers on physic-chemical properties of soils under chilli cultivation.

\section{Materials and Methods}

\section{General description of the area}

\section{Experimental site}

A field experiment was conducted at research and demonstration block of Research Institute on Organic Farming, University of Agricultural Sciences, Gandhi Krishi Vignana Kendra, Bengaluru which is situated in Eastern dry zone of Karnataka at a latitude of $12^{\circ} 58^{\prime}$ North, longitude of $75^{\circ} 35^{\prime}$ East and at an altitude of $930 \mathrm{~m}$ above mean sea level. The experiment was conducted to study the combined effect of different sources of organic manure, Jeevamrutha and decomposers on growth and yield of chilli during kharif - 2017 and 2018 under irrigated condition.

\section{Climate and weather}

The normal annual rainfall of the station was 920.5 and $919.65 \mathrm{~mm}$ in 2017 and 2018, respectively. The major portion of rainfall was 
received during September (197 $\mathrm{mm}$ in 2017 and $195.21 \mathrm{~mm}$ in 2018). The maximum temperature was ranged from $26.2^{\circ} \mathrm{C}$ in December to $33.8^{\circ} \mathrm{C}$ in April during 2017. In 2018 , it was ranged from $25.62^{\circ} \mathrm{C}$ in December to $33.05^{\circ} \mathrm{C}$ in April. The monthly relative humidity was ranged from 75.3 per cent in March to 89.0 per cent in August during 2017. In 2018, it was ranged from 73.9 per cent in March to 87.0 per cent in August. During 2017, bright sunshine hours was maximum during February (9.4 hrs.) and the lowest in July (4.3 hrs.), during 2018 maximum was recorded in February (9.1 hrs.) and lowest in the month July (4.2 hrs.) and the wind speed during 2017 was maximum in the month of June (12.8 $\left.\mathrm{km} \mathrm{hr}^{-1}\right)$ and minimum in October $\left(5.5 \mathrm{~km} \mathrm{hr}^{-1}\right)$, during 2018, it was maximum during June $\left(12.4 \mathrm{~km} \mathrm{hr}^{-1}\right)$ and the minimum in October $\left(5.3 \mathrm{~km} \mathrm{hr}^{-1}\right)$. The open pan evaporation was directly related to maximum and minimum temperature of the month and followed the same trend as that of maximum temperature with maximum in both year during April (7.7 and $7.3 \mathrm{~mm}$ day $\left.^{-1}\right)$ and December (4.5 and $4.4 \mathrm{~mm} \mathrm{day}^{-1}$ ) during 2017 and 2018, respectively.

\section{Soil}

Soil of the experimental site was red sandy loam with a pH of 6.93 , EC $\left(0.27 \mathrm{dSm}^{-1}\right)$, low in organic carbon $(0.44 \%)$ and medium in available nitrogen $\left(292 \mathrm{~kg} \mathrm{ha}^{-1}\right), \mathrm{P}_{2} \mathrm{O}_{5}(27 \mathrm{~kg}$ $\left.\mathrm{ha}^{-1}\right)$ and $\mathrm{K}_{2} \mathrm{O}\left(241 \mathrm{~kg} \mathrm{ha}^{-1}\right)$.

\section{Experimental details}

The experiment was laid out on factorial Randomized Block Design with 12 treatments viz., $\mathrm{T}_{1}$ : FYM $\mathrm{x}$ Jeevamrutha, $\mathrm{T}_{2}$ : FYM $\mathrm{x}$ Microbial consortia, $\mathrm{T}_{3}$ : FYM x Decomposer, $\mathrm{T}_{4}$ : Vermicompost $\mathrm{x}$ Jeevamrutha, $\mathrm{T}_{5}$ : Vermicompost $\mathrm{x}$ Microbial consortia, $\mathrm{T}_{6}$ : Vermicompost $\mathrm{x}$ Decomposer, $\mathrm{T}_{7}$ : Poultry manure $\mathrm{x}$ Jeevamrutha, $\mathrm{T}_{8}$ : Poultry manure $\mathrm{x}$
Microbial consortia, $\mathrm{T}_{9}$ : Poultry manure $\mathrm{x}$ Decomposer, $\mathrm{T}_{10}$ : Sheep manure $\mathrm{x}$ Jeevamrutha, $\mathrm{T}_{11}$ : Sheep manure $\mathrm{x}$ Microbial consortia and $\mathrm{T}_{12}$ :Sheep manure $\mathrm{x}$ Decomposer and replicated thrice. Recommended dose of nutrients for chilli is 150:75:75 N: $\mathrm{P}_{2} \mathrm{O}_{5}: \mathrm{K}_{2} \mathrm{O} \mathrm{kg} \mathrm{ha}{ }^{-1}$ and nutrients were supplied through FYM, vermicompost, poultry manures and sheep manures on the basis of nitrogen equivalent. Treatment combinations consisted of four different organic sources $\left(\mathrm{M}_{1}\right.$ : $\mathrm{FYM}, \mathrm{M}_{2}$ : Vermicompost, $\mathbf{M}_{3}$ : Poultry Manure and $\mathrm{M}_{4}$ : Sheep manures-100 \% N equivalent basis), three decomposers $\left(\mathrm{J}_{1}\right.$ : Jeevamrutha, $\mathrm{C}_{2}$ : Microbial consortia and $\mathrm{N}_{3}$ : decomposer developed by NCOF. All the different sources of organic manure were incorporated into the soil, three weeks prior to sowing.

\section{Soil sampling}

Surface $(0-15 \mathrm{~cm})$ and subsurface $(15-30 \mathrm{~cm})$ soil samples were collected before sowing and after the harvest of the three cropping sequences and were air dried and grinded in a wooden pestle and mortar to pass through 2 $\mathrm{mm}$ sieve and subsequently stored in polyethylene bags for determination of physical parameters.

\section{Results and Discussion}

\section{Bulk density}

Significantly lower bulk density was observed with vermicomposting application $\left(1.33 \mathrm{~g} \mathrm{cc}^{-1}\right.$ and $1.29 \mathrm{~g} \mathrm{cc}^{-1}$ during 2017 and 2018 respectively) and higher bulk density was observed in application of FYM $\left(1.42 \mathrm{~g} \mathrm{cc}^{-1}\right.$ and $1.35 \mathrm{~g} \mathrm{cc}^{-1}$ during 2017 and 2018 respectively). Soil application of jeevamrutha recorded significantly lower bulk density $(1.24$ $\mathrm{g} \mathrm{cc}^{-1}$ and $1.19 \mathrm{~g} \mathrm{cc}^{-1}$ during 2017 and 2018 respectively) and higher bulk density was observed in application of NCOF- 
decomposers (1.48 $\mathrm{g} \mathrm{cc}^{-1}$ and $1.40 \mathrm{~g} \mathrm{cc}^{-1}$ during 2017 and 2018 respectively). Interaction effects of these two factors didn't differ significantly.

\section{Maximum water holding capacity}

\section{Kharif, 2017}

Significantly higher maximum water holding capacity was observed with vermicompost application (35.49 and 37.70 \% during 2017 and 2018 respectively) as compared to FYM (31.67 and $33.46 \%$ during 2017 and 2018 respectively) and it was on par with the application of poultry manure (33.63 and $35.64 \%$ during 2017 and 2018 respectively).

Soil application of jeevamrutha recorded significantly higher maximum water holding capacity (36.95 and $39.32 \%$ during 2017 and 2018 respectively) as compared to application of decomposer (28.16 and $29.54 \%$ during 2017 and 2018 respectively) and was on par with the application of microbial consortia (34.97 and $37.13 \%$ during 2017 and 2018 respectively). Interaction effects of these two factors didn't differ significantly.

\section{Infiltration rate}

Significantly higher infiltration rate was observed with vermicompost application (7.48 $\mathrm{cm} \mathrm{hr}^{-1}$ and $8.28 \mathrm{~cm} \mathrm{hr}^{-1}$ ) as compared to FYM (6.68 $\mathrm{cm} \mathrm{hr}^{-1}$ and $7.34 \mathrm{~cm} \mathrm{hr}^{-1}$ ) and it was on par with the application of poultry manure (7.09 $\mathrm{cm} \mathrm{hr}^{-1}$ and $7.82 \mathrm{~cm} \mathrm{hr}^{-1}$ ). Soil application of jeevamrutha recorded higher infiltration rate was $\left(7.79 \mathrm{~cm} \mathrm{hr}^{-1}\right.$ and $8.63 \mathrm{~cm}$ $\left.\mathrm{hr}^{-1}\right)$ as compared to application of decomposer (5.94 $\mathrm{cm} \mathrm{hr}^{-1}$ and $6.48 \mathrm{~cm} \mathrm{hr}^{-1}$ ) when was on par with the application of poultry manure $\left(7.37 \mathrm{~cm} \mathrm{hr}^{-1}\right.$ and 8.15 $\mathrm{cm} \mathrm{hr} \mathrm{hr}^{-1}$ ). Interaction effects of these two factors didn't differ significantly.

\section{Soil pH}

Soil $\mathrm{pH}$ didn't differ significantly due to the application of different sources of application of FYM, vermicompost, poultry manure and sheep manure and also with the application of jeevamrutha, microbial consortia and decomposers. Numerically, lower soil $\mathrm{pH}$ (6.34 and 6.80 during both the season respectively) was observed with FYM at 100 per cent $\mathrm{N}$ equivalent and higher $\mathrm{pH}$ was observed with application of sheep manure (6.57 and 6.89 during both the season respectively). Interaction effects of these two factors didn't differ significantly.

\section{Electrical conductivity}

Electrical conductivity differed significantly due to the application of different sources of application of FYM, vermicompost, poultry manure and sheep manure and also with the application of jeevamrutha, microbial consortia and decomposers. Significantly higher electrical conductivity $\left(0.21 \mathrm{dS} \mathrm{m}^{-1}\right.$ and $0.24 \mathrm{dS} \mathrm{m}^{-1}$ during both the season respectivly) was observed with vermicompost application and lower electrical conductivity was observed with application of sheep manure $\left(0.17 \mathrm{dS} \mathrm{m}^{-1}\right.$ and $0.21 \mathrm{dS} \mathrm{m}^{-1}$ during both the season). Interaction effects of these two factors didn't differ significantly.

\section{Organic carbon}

Organic carbon of soil differed significantly due to the application of different sources of application of FYM, vermicompost, poultry manure and sheep manure but it showed nonsignificant results with the application of jeevamrutha, microbial consortia and decomposers. Significantly higher organic carbon $(0.49$ and $0.50 \%$ during both the season respectively) was observed with poultry manure application and lower organic carbon was observed with application of sheep 
manure $(0.45$ and $0.47 \%$ during both the season respectively). Interaction effects of these two factors didn't differ significantly.

\section{Crop yield}

Among the different organics treatment effect, application of vermicompost had recorded significantly higher green chill yield $(20.47 \mathrm{t}$ $\mathrm{ha}^{-1}$ and 23.09t ha ${ }^{-1}$ during both the season respectively) and was at par with the application of poultry manure $\left(19.40 \mathrm{tha}^{-1}\right.$ and $21.85 \mathrm{t} \mathrm{ha}^{-1}$ during both the season respectively) whereas; significantly lower green chilli yield (18.27 tha $\mathrm{th}^{-1}$ and $20.54 \mathrm{t} \mathrm{ha}^{-1}$ during both the season respectively) was noticed in FYM. Soil application of jeevamrutha recorded significantly higher green chilli yield $\left(21.31 \mathrm{t} \mathrm{ha}^{-1}\right.$ and $24.06 \mathrm{t} \mathrm{ha}^{-1}$ during both the season respectively) and it was on par with the application of microbial consortia (20.17 t ha ${ }^{-1}$ and $22.74 \mathrm{t} \mathrm{ha}^{-1}$ during both the season respectively) whereas; significantly lower green chilli yield $(16.24 \mathrm{t}$ $\mathrm{ha}^{-1}$ and $18.20 \mathrm{t} \mathrm{ha}^{-1}$ during both the season respectively) was observed in application of NCOF- decomposers. Interaction effects of these two factors didn't differ significantly.

\section{Straw yield}

Application of vermicompost had recorded significantly higher stalk yield (5.28and $6.15 \mathrm{t}$ $\mathrm{ha}^{-1}$ ) as compared to FYM (4.74 and $5.50 \mathrm{t}$ $\mathrm{ha}^{-1}$ ) and it was on par with the application of poultry manure (5.01 and $\left.5.83 \mathrm{t} \mathrm{ha}^{-1}\right)$. Soil application of jeevamrutha recorded significantly higher stalk yield (5.50 and $6.41 \mathrm{t}$ $\left.\mathrm{ha}^{-1}\right)$ as compared to application of decomposers (4.21 and $6.07 \mathrm{t} \mathrm{ha}^{-1}$ ) and it was on par with the application of microbial consortia. Interaction effects of organic manures and decomposer didn't differ significantly.
Wormcasts are a resource that may be used in agriculture because of their effects on nutrient dynamic and the physical structure of soil may significantly enhance plant growth and conserve better soil status (Lee, 1985). Earthworm casts are usually considered to be responsible for a good soil structure and improve soil physical properties i.e. infiltration, water retention and resistance to erosion (Rose and Wood, 1980). Lee (1985) reported that the hydraulic conductivity increased by 80 per cent and water infiltration by six fold.

Among the application of different organic manure, application of poultry manure through $\mathrm{N}$ equivalent recorded higher organic carbon content (0.49 and $0.50 \%)$, higher $\mathrm{pH}$ with sheep manure (6.57 and 6.89), higher EC $\left(0.21\right.$ and $\left.0.24 \mathrm{dSm}^{-1}\right)$, lower BD (1.20 and $1.26 \mathrm{~g} \mathrm{~cm}^{-3}$ ) and higher MWHC (35.49 and $37.70 \%$ ) with vermicompost as compared to rest other organic treatment (Table 2, 3, 4 and 5). These finding are in line with the Hangarge et al., (2004) reported higher organic carbon content, higher $\mathrm{pH}$ and $\mathrm{EC}$ with the combined application of organics (vermicompost @ 5 t/ha) + liquid organics (cow dung slurry @ 1 $1 / \mathrm{m}^{2}$ and organic booster @ $11 / \mathrm{m}^{2}$ ) against initial values and after harvest of chilli.

During the process of decomposition many intermediate compounds, organic acids and humic substance will be produced. These substances will act as cementing for aggregation of soil particles resulting in improvement in soil structure. These results are similar to the findings of Martin (1991) reported that earthworm casts had increased the proportion of macro-aggregates significantly from 25.4 to 31.2 per cent. Kale et al., (1992) found that the application of earthworm casts to fields can improve the physio-chemical and biological properties of the soil. 
Table.1 Green chilli yield and stalk yield of chilli as influenced by application of organic manures, jeevamrutha and decomposers during kharif 2017 and 2018

\begin{tabular}{|c|c|c|c|c|c|c|c|c|}
\hline \multirow[t]{4}{*}{ Manures } & \multicolumn{8}{|c|}{ Green chilli yield (t ha ${ }^{-1}$ ) } \\
\hline & \multicolumn{4}{|c|}{2017} & \multicolumn{4}{|c|}{2018} \\
\hline & \multicolumn{4}{|c|}{ Decomposers } & \multicolumn{4}{|c|}{ Decomposers } \\
\hline & $\mathbf{J}$ & $\mathbf{C}$ & $\mathbf{N}$ & Mean & $\mathbf{J}$ & $\mathbf{C}$ & $\mathbf{N}$ & Mean \\
\hline FYM & 20.66 & 19.30 & 14.85 & 18.27 & 23.30 & 21.73 & 16.59 & 20.54 \\
\hline VC & 22.30 & 20.61 & 18.51 & 20.47 & 25.20 & 23.24 & 20.81 & 23.09 \\
\hline PM & 21.38 & 20.59 & 16.22 & 19.40 & 24.14 & 23.23 & 18.17 & 21.85 \\
\hline SM & 20.90 & 20.19 & 15.39 & 18.83 & 23.59 & 22.76 & 17.21 & 21.19 \\
\hline \multirow[t]{2}{*}{ Mean } & 21.31 & 20.17 & 16.24 & & 24.06 & 22.74 & 18.20 & \\
\hline & \multicolumn{2}{|c|}{ S.Em \pm} & \multicolumn{2}{|c|}{$\mathrm{CD}(\mathrm{P}=\mathbf{0 . 0 5})$} & \multicolumn{2}{|c|}{ S.Em \pm} & \multicolumn{2}{|c|}{$\mathrm{CD}(\mathrm{P}=0.05)$} \\
\hline $\mathbf{M}$ & \multicolumn{2}{|c|}{0.510} & \multicolumn{2}{|c|}{1.496} & \multicolumn{2}{|c|}{0.596} & \multicolumn{2}{|c|}{1.749} \\
\hline D & \multicolumn{2}{|c|}{0.442} & \multicolumn{2}{|c|}{1.295} & \multicolumn{2}{|c|}{0.516} & \multicolumn{2}{|c|}{1.514} \\
\hline$M \times D$ & \multicolumn{2}{|c|}{0.883} & \multicolumn{2}{|c|}{ NS } & \multicolumn{2}{|c|}{1.033} & \multicolumn{2}{|c|}{ NS } \\
\hline \multirow[t]{4}{*}{ Manures } & \multicolumn{8}{|c|}{ Stalk yield $\left(\mathrm{t} \mathrm{ha}{ }^{-1}\right)$} \\
\hline & \multicolumn{4}{|c|}{2017} & \multicolumn{4}{|c|}{2018} \\
\hline & \multicolumn{4}{|c|}{ Decomposers } & \multicolumn{4}{|c|}{ Decomposers } \\
\hline & $\mathbf{J}$ & $\mathbf{C}$ & $\mathbf{N}$ & Mean & $\mathbf{J}$ & $\mathbf{C}$ & $\mathbf{N}$ & Mean \\
\hline FYM & 5.34 & 4.99 & 3.87 & 4.74 & 6.22 & 5.81 & 4.48 & 5.50 \\
\hline VC & 5.75 & 5.32 & 4.78 & 5.28 & 6.71 & 6.20 & 5.56 & 6.15 \\
\hline PM & 5.52 & 5.31 & 4.20 & 5.01 & 6.43 & 6.19 & 4.86 & 5.83 \\
\hline SM & 5.39 & 5.21 & 3.98 & 4.86 & 6.29 & 6.07 & 4.61 & 5.65 \\
\hline \multirow[t]{2}{*}{ Mean } & 5.50 & 5.21 & 4.21 & & 6.41 & 6.07 & 4.88 & \\
\hline & \multicolumn{2}{|c|}{ S.Em \pm} & \multicolumn{2}{|c|}{ CD $(P=0.05)$} & & & CD (I & $=0.05)$ \\
\hline M & & & & & & & & \\
\hline D & & & & & & & & \\
\hline M $\times D$ & & & & & & & & \\
\hline
\end{tabular}

CD at $5 \%$ NS - Non-significant DAT- Days after Transplanting M - Manures

RDF: $125: 75: 63 \mathrm{~kg} \mathrm{~N}: \mathrm{P}_{2} \mathrm{O}_{5}: \mathrm{K}_{2} \mathrm{O}$ ha $^{-1}$ for $\mathrm{N}$ equivalent FYM application D - Decomposers

FYM - Farm yard manure VC - Vermicompost PM - Poultry manure SM - Sheep manure

J - Jeevamrutha $\quad \mathbf{C}$ - Microbial Consortia $\quad \mathbf{N}$ - Decomposer from NCOF 
Table.2 Physical properties of soil at harvest of chilli as influenced by application of organic manures, jeevamrutha and decomposers during kharif 2017

\begin{tabular}{|c|c|c|c|c|c|c|c|c|}
\hline \multirow[t]{4}{*}{ Manures } & \multicolumn{8}{|c|}{ Physical properties } \\
\hline & \multicolumn{4}{|c|}{$\mathrm{BD}\left(\mathrm{g} \mathrm{ce}^{-1}\right)$} & \multicolumn{4}{|c|}{ MWHC (\%) } \\
\hline & \multicolumn{4}{|c|}{ Decomposers } & \multicolumn{4}{|c|}{ Decomposers } \\
\hline & $\mathbf{J}$ & $\mathrm{C}$ & $\mathbf{N}$ & Mean & $\mathbf{J}$ & $\mathbf{C}$ & $\mathbf{N}$ & Mean \\
\hline FYM & 1.27 & 1.53 & 1.43 & 1.42 & 35.81 & 33.46 & 25.74 & 31.67 \\
\hline VC & 1.22 & 1.23 & 1.55 & 1.33 & 38.66 & 35.72 & 32.08 & 35.49 \\
\hline PM & 1.24 & 1.43 & 1.48 & 1.38 & 37.07 & 35.70 & 28.12 & 33.63 \\
\hline SM & 1.23 & 1.40 & 1.45 & 1.36 & 36.24 & 35.00 & 26.88 & 32.64 \\
\hline \multirow[t]{2}{*}{ Mean } & 1.24 & 1.40 & 1.48 & & 36.95 & 34.97 & 28.16 & \\
\hline & \multicolumn{2}{|c|}{ S.Em \pm} & \multicolumn{2}{|c|}{$\mathrm{CD}(\mathrm{P}=0.05)$} & \multicolumn{2}{|c|}{ S.Em \pm} & \multicolumn{2}{|c|}{$\mathrm{CD}(\mathrm{P}=\mathbf{0 . 0 5})$} \\
\hline $\mathbf{M}$ & \multicolumn{2}{|c|}{0.037} & \multicolumn{2}{|c|}{0.107} & \multicolumn{2}{|c|}{0.884} & \multicolumn{2}{|c|}{2.593} \\
\hline D & \multicolumn{2}{|c|}{0.032} & \multicolumn{2}{|c|}{0.093} & \multicolumn{2}{|c|}{0.766} & \multicolumn{2}{|c|}{2.246} \\
\hline$M \times D$ & \multicolumn{2}{|c|}{0.063} & \multicolumn{2}{|c|}{ NS } & \multicolumn{2}{|c|}{1.531} & \multicolumn{2}{|c|}{ NS } \\
\hline \multirow[t]{4}{*}{ Manures } & \multicolumn{8}{|c|}{ Physical properties } \\
\hline & \multicolumn{4}{|c|}{ Infiltration rate $\left(\mathrm{cm} \mathrm{hr}^{-1}\right)$} & & & & \\
\hline & \multicolumn{4}{|c|}{ Decomposers } & & & & \\
\hline & $\mathbf{J}$ & $\mathbf{C}$ & $\mathbf{N}$ & Mean & & & & \\
\hline FYM & 7.55 & 7.05 & 5.43 & 6.68 & & & & \\
\hline VC & 8.15 & 7.53 & 6.76 & 7.48 & & & & \\
\hline PM & 7.81 & 7.53 & 5.93 & 7.09 & & & & \\
\hline SM & 7.64 & 7.38 & 5.62 & 6.88 & & & & \\
\hline \multirow[t]{2}{*}{ Mean } & 7.79 & 7.37 & 5.94 & & & & & \\
\hline & \multicolumn{2}{|c|}{ S.Em \pm} & \multicolumn{2}{|c|}{$\mathrm{CD}(\mathrm{P}=0.05)$} & & & & \\
\hline $\mathbf{M}$ & \multicolumn{2}{|c|}{0.186} & & & & & & \\
\hline D & & & & & & & & \\
\hline Mx D & & & & & & & & \\
\hline $\begin{array}{l}\text { D at } 5 \% \\
\text { SDF: } 125: 75: 6 \\
\text { YM - Farm ya } \\
\text { - Jeevamrutha }\end{array}$ & $\begin{array}{l}-\mathrm{Non}-\mathrm{s} \\
\mathrm{g} \mathrm{N}: \mathrm{P}_{2} \mathrm{O} \\
\text { manure } \\
\mathrm{C}-\mathrm{Mi}\end{array}$ & $\begin{array}{l}\text { ficant } \\
{ }_{2} \mathrm{O} \mathrm{ha}^{-} \\
\mathrm{C}-\mathrm{Ver} \\
\text { bial Co }\end{array}$ & $\begin{array}{l}\text { AT- D } \\
\text { N equi } \\
\text { mpost } \\
\text { tia N N }\end{array}$ & $\begin{array}{l}\text { after Tra } \\
\text { ent FYM } \\
\text { M - Poult } \\
\text { ecompos }\end{array}$ & $\begin{array}{l}\text { planting } \\
\text { plication } \\
\text { manure } \\
\text { from NC }\end{array}$ & $\begin{array}{l}\text { M - M } \\
- \text { - Decc } \\
\text { M - She }\end{array}$ & $\begin{array}{l}\text { es } \\
\text { sers } \\
\text { anure }\end{array}$ & \\
\hline
\end{tabular}


Table.3 Physical properties of soil at harvest of chilli as influenced by application of organic manures, jeevamrutha and decomposers during kharif 2018

\begin{tabular}{|c|c|c|c|c|c|c|c|c|}
\hline \multirow[t]{4}{*}{ Manures } & \multicolumn{8}{|c|}{ Physical properties } \\
\hline & \multicolumn{4}{|c|}{ BD $\left(\mathrm{g} \mathrm{ce}^{-1}\right)$} & \multicolumn{4}{|c|}{ MWHC (\%) } \\
\hline & \multicolumn{4}{|c|}{ Decomposers } & \multicolumn{4}{|c|}{ Decomposers } \\
\hline & $\mathbf{J}$ & $\mathbf{C}$ & $\mathbf{N}$ & Mean & $\mathbf{J}$ & $\mathbf{C}$ & $\mathbf{N}$ & Mean \\
\hline FYM & 1.22 & 1.46 & 1.36 & 1.35 & 38.06 & 35.44 & 26.86 & 33.46 \\
\hline VC & 1.18 & 1.27 & 1.47 & 1.29 & 41.23 & 37.96 & 33.91 & 37.70 \\
\hline PM & 1.20 & 1.36 & 1.41 & 1.32 & 39.46 & 37.94 & 29.51 & 35.64 \\
\hline SM & 1.19 & 1.33 & 1.38 & 1.30 & 35.54 & 37.16 & 27.90 & 34.53 \\
\hline \multirow[t]{2}{*}{ Mean } & 1.19 & 1.35 & 1.40 & & 39.32 & 37.13 & 29.54 & \\
\hline & \multicolumn{2}{|c|}{ S.Em \pm} & \multicolumn{2}{|c|}{$\mathrm{CD}(\mathrm{P}=0.05)$} & \multicolumn{2}{|c|}{ S.Em \pm} & \multicolumn{2}{|c|}{$\mathrm{CD}(\mathrm{P}=0.05)$} \\
\hline $\mathbf{M}$ & \multicolumn{2}{|c|}{0.034} & \multicolumn{2}{|c|}{0.099} & \multicolumn{2}{|c|}{0.972} & \multicolumn{2}{|c|}{2.851} \\
\hline D & \multicolumn{2}{|c|}{0.029} & \multicolumn{2}{|c|}{0.085} & \multicolumn{2}{|c|}{0.842} & \multicolumn{2}{|c|}{2.469} \\
\hline$M \times D$ & \multicolumn{2}{|c|}{0.058} & \multicolumn{2}{|c|}{ NS } & \multicolumn{2}{|c|}{1.684} & \multicolumn{2}{|c|}{ NS } \\
\hline \multirow[t]{4}{*}{ Manures } & \multicolumn{8}{|c|}{ Physical properties } \\
\hline & \multicolumn{4}{|c|}{ Infiltration rate $\left(\mathrm{cm} \mathrm{hr}^{-1}\right)$} & & & & \\
\hline & \multicolumn{4}{|c|}{ Decomposers } & & & & \\
\hline & $\mathbf{J}$ & $\mathbf{C}$ & $\mathbf{N}$ & Mean & & & & \\
\hline FYM & 8.36 & 7.78 & 5.90 & 7.34 & & & & \\
\hline VC & 9.05 & 8.33 & 7.44 & 8.28 & & & & \\
\hline PM & 8.66 & 8.33 & 6.48 & 7.82 & & & & \\
\hline SM & 8.46 & 8.16 & 6.12 & 7.58 & & & & \\
\hline \multirow[t]{2}{*}{ Mean } & 8.63 & 8.15 & 6.48 & & & & & \\
\hline & \multicolumn{2}{|c|}{ S.Em \pm} & \multicolumn{2}{|c|}{$\mathrm{CD}(\mathrm{P}=0.05)$} & & & & \\
\hline M & \multicolumn{2}{|c|}{0.213} & & & & & & \\
\hline D & & & & & & & & \\
\hline M $\times D$ & & & & & & & & \\
\hline $\begin{array}{l}\text { CD at } 5 \% \\
\text { RDF: } 125: 75: 6 \\
\text { FYM - Farm ya } \\
\text { J - Jeevamruth }\end{array}$ & $\begin{array}{l}\text { - Non- } \\
\text { g N:P } \\
\text { manure } \\
\mathrm{C}-\mathrm{N}\end{array}$ & $\begin{array}{l}\text { ificant } \\
\mathrm{C}_{2} \mathrm{O} \text { ha } \\
\mathrm{C}-\mathrm{Ver} \\
\text { bial Co }\end{array}$ & $\begin{array}{l}\text { DAT- I } \\
\text { r N equ } \\
\text { ompost } \\
\text { rtia I }\end{array}$ & $\begin{array}{l}\text { after Tr } \\
\text { ent FYM } \\
\text { M - Pou } \\
\text { ecompo }\end{array}$ & $\begin{array}{l}\text { lanting } \\
\text { licatio } \\
\text { manure } \\
\text { rom N }\end{array}$ & $\begin{array}{l}\mathbf{M}-\mathbf{N} \\
\mathbf{D}-\mathrm{De} \\
\mathbf{M}-\mathrm{Sh} \\
\mathrm{F}\end{array}$ & $\begin{array}{l}\text { es } \\
\text { osers } \\
\text { lanure }\end{array}$ & \\
\hline
\end{tabular}


Table.4 Chemical properties of soil at harvest of chilli as influenced by application of organic manures, jeevamrutha and decomposers during kharif 2017

\begin{tabular}{|c|c|c|c|c|c|c|c|c|}
\hline \multirow[t]{4}{*}{ Manures } & \multicolumn{8}{|c|}{ Chemical properties } \\
\hline & \multicolumn{4}{|c|}{ pH } & \multicolumn{4}{|c|}{$\mathrm{EC}\left(\mathrm{dSm}^{-1}\right)$} \\
\hline & \multicolumn{4}{|c|}{ Decomposers } & \multicolumn{4}{|c|}{ Decomposers } \\
\hline & $\mathbf{J}$ & $\mathbf{C}$ & $\mathbf{N}$ & Mean & $\mathbf{J}$ & $\mathbf{C}$ & $\mathbf{N}$ & Mean \\
\hline FYM & 6.36 & 6.35 & 6.30 & 6.34 & 0.18 & 0.20 & 0.21 & 0.19 \\
\hline VC & 6.50 & 6.49 & 6.44 & 6.48 & 0.22 & 0.21 & 0.19 & 0.21 \\
\hline PM & 6.41 & 6.40 & 6.38 & 6.40 & 0.17 & 0.20 & 0.19 & 0.18 \\
\hline $\mathbf{S M}$ & 6.59 & 6.58 & 6.55 & 6.57 & 0.15 & 0.18 & 0.17 & 0.17 \\
\hline \multirow[t]{2}{*}{ Mean } & 6.46 & 6.46 & 6.42 & & 0.18 & 0.19 & 0.19 & \\
\hline & \multicolumn{2}{|c|}{ S.Em \pm} & \multicolumn{2}{|c|}{$\mathrm{CD}(\mathrm{P}=0.05)$} & \multicolumn{2}{|c|}{ S.Em \pm} & \multicolumn{2}{|c|}{$\mathrm{CD}(P=0.05)$} \\
\hline $\mathbf{M}$ & \multicolumn{2}{|c|}{0.287} & \multicolumn{2}{|c|}{ NS } & \multicolumn{2}{|c|}{0.009} & \multicolumn{2}{|c|}{0.0018} \\
\hline D & \multicolumn{2}{|c|}{0.249} & \multicolumn{2}{|c|}{ NS } & \multicolumn{2}{|c|}{0.008} & \multicolumn{2}{|c|}{ NS } \\
\hline$M \times D$ & \multicolumn{2}{|c|}{0.497} & \multicolumn{2}{|c|}{ NS } & \multicolumn{2}{|c|}{0.015} & \multicolumn{2}{|c|}{ NS } \\
\hline \multirow[t]{4}{*}{ Manures } & \multicolumn{8}{|c|}{ Chemical properties } \\
\hline & \multicolumn{4}{|c|}{$\mathrm{OC}(\%)$} & & & & \\
\hline & \multicolumn{4}{|c|}{ Decomposers } & & & & \\
\hline & $\mathbf{J}$ & $\mathbf{C}$ & $\mathbf{N}$ & Mean & & & & \\
\hline FYM & 0.50 & 0.45 & 0.42 & 0.46 & & & & \\
\hline VC & 0.52 & 0.47 & 0.44 & 0.48 & & & & \\
\hline PM & 0.55 & 0.48 & 0.45 & 0.49 & & & & \\
\hline SM & 0.50 & 0.46 & 0.41 & 0.45 & & & & \\
\hline \multirow[t]{2}{*}{ Mean } & 0.52 & 0.47 & 0.44 & & & & & \\
\hline & \multicolumn{2}{|c|}{ S.Em \pm} & \multicolumn{2}{|c|}{$\mathrm{CD}(\mathrm{P}=\mathbf{0 . 0 5})$} & & & & \\
\hline M & \multicolumn{2}{|c|}{0.013} & & & & & & \\
\hline D & & & & & & & & \\
\hline$M \times D$ & & & & & & & & \\
\hline $\begin{array}{l}\text { CD at } 5 \% \\
\text { RDF: } 125: 75: 6 \\
\text { FYM - Farm ya } \\
\text { J - Jeevamruth }\end{array}$ & $\begin{array}{l}\text { - Non-s } \\
\text { g N:P } \mathrm{P}_{2} \mathrm{C} \\
\text { manure } \\
\mathrm{C}-\mathrm{M}\end{array}$ & $\begin{array}{l}\text { ificant } \\
{ }_{2} \mathrm{O} \text { ha }^{-1} \\
\text { C - Verr } \\
\text { bial Cor }\end{array}$ & $\begin{array}{l}\text { DAT- D } \\
\text { r N equ } \\
\text { ompost } \\
\text { rtia N }\end{array}$ & $\begin{array}{l}\text { S after Tr } \\
\text { lent FYM } \\
\text { M - Pou } \\
\text { Decompo }\end{array}$ & $\begin{array}{l}\text { plantins } \\
\text { plicatio } \\
\text { manur } \\
\text { from N }\end{array}$ & $\begin{array}{l}\text { M - N } \\
- \text { Dec } \\
\text { M - Sh }\end{array}$ & $\begin{array}{l}\text { res } \\
\text { posers } \\
\text { manure }\end{array}$ & \\
\hline
\end{tabular}


Table.5 Chemical properties of soil at harvest of chilli as influenced by application of organic manures, jeevamrutha and decomposers during kharif 2018

\begin{tabular}{|c|c|c|c|c|c|c|c|c|}
\hline \multirow[t]{4}{*}{ Manures } & \multicolumn{8}{|c|}{ Chemical properties } \\
\hline & \multicolumn{4}{|c|}{ pH } & \multicolumn{4}{|c|}{$\mathrm{EC}\left(\mathrm{dSm}^{-1}\right)$} \\
\hline & \multicolumn{4}{|c|}{ Decomposers } & \multicolumn{4}{|c|}{ Decomposers } \\
\hline & $\mathbf{J}$ & $\mathbf{C}$ & $\mathbf{N}$ & Mean & $\mathbf{J}$ & $\mathbf{C}$ & $\mathbf{N}$ & Mean \\
\hline FYM & 6.90 & 6.80 & 6.70 & 6.80 & 0.23 & 0.21 & 0.23 & 0.22 \\
\hline VC & 6.95 & 6.81 & 6.75 & 6.84 & 0.25 & 0.25 & 0.20 & 0.24 \\
\hline PM & 6.98 & 6.84 & 6.76 & 6.86 & 0.21 & 0.25 & 0.23 & 0.23 \\
\hline SM & 6.99 & 6.89 & 6.78 & 6.89 & 0.23 & 0.21 & 0.23 & 0.21 \\
\hline \multirow[t]{2}{*}{ Mean } & 6.96 & 6.84 & 6.75 & & 0.23 & 0.23 & 0.22 & \\
\hline & \multicolumn{2}{|c|}{ S.Em \pm} & \multicolumn{2}{|c|}{$\mathrm{CD}(\mathrm{P}=0.05)$} & \multicolumn{2}{|c|}{ S.Em \pm} & \multicolumn{2}{|c|}{$\mathrm{CD}(\mathrm{P}=0.05)$} \\
\hline $\mathbf{M}$ & \multicolumn{2}{|c|}{0.191} & \multicolumn{2}{|c|}{ NS } & \multicolumn{2}{|c|}{0.010} & \multicolumn{2}{|c|}{ NS } \\
\hline $\mathbf{D}$ & \multicolumn{2}{|c|}{0.166} & \multicolumn{2}{|c|}{ NS } & \multicolumn{2}{|c|}{0.008} & \multicolumn{2}{|c|}{ NS } \\
\hline $\mathbf{M} \times \mathbf{D}$ & \multicolumn{2}{|c|}{0.331} & \multicolumn{2}{|c|}{ NS } & \multicolumn{2}{|c|}{0.017} & \multicolumn{2}{|c|}{ NS } \\
\hline \multirow[t]{4}{*}{ Manures } & \multicolumn{8}{|c|}{ Chemical properties } \\
\hline & \multicolumn{4}{|c|}{$\mathrm{OC}(\%)$} & & & & \\
\hline & \multicolumn{4}{|c|}{ Decomposers } & & & & \\
\hline & $\mathbf{J}$ & $\mathbf{C}$ & $\mathbf{N}$ & Mean & & & & \\
\hline FYM & 0.51 & 0.46 & 0.43 & 0.48 & & & & \\
\hline $\mathrm{VC}$ & 0.53 & 0.48 & 0.45 & 0.49 & & & & \\
\hline $\mathbf{P M}$ & 0.56 & 0.49 & 0.46 & 0.50 & & & & \\
\hline SM & 0.51 & 0.47 & 0.45 & 0.47 & & & & \\
\hline \multirow[t]{2}{*}{ Mean } & 0.53 & 0.48 & 0.45 & & & & & \\
\hline & \multicolumn{2}{|c|}{ S.Em \pm} & \multicolumn{2}{|c|}{$\mathrm{CD}(\mathrm{P}=0.05)$} & & & & \\
\hline $\mathbf{M}$ & \multicolumn{2}{|c|}{0.013} & & & & & & \\
\hline D & & & & & & & & \\
\hline M x D & & & & & & & & \\
\hline $\begin{array}{l}\text { CD at } 5 \% \\
\text { RDF: } 125: 75: 6 \\
\text { YM - Farm yar } \\
\text { - Jeevamrutha }\end{array}$ & $\begin{array}{l}\text { - Non-si } \\
\mathrm{N}: \mathrm{P}_{2} \mathrm{O} \\
\text { hanure } \\
\mathrm{C}-\mathrm{Mic}\end{array}$ & $\begin{array}{l}\text { ficant } \\
{ }_{2} \mathrm{O} \text { ha }^{-1} \\
\text { - Verm } \\
\text { ial Cons }\end{array}$ & $\begin{array}{l}\text { AT- } \mathrm{Da} \\
\mathrm{N} \text { equiv } \\
\text { mpost } \\
\text { ia } \mathbf{N} \text { - }\end{array}$ & $\begin{array}{l}\text { after Tra } \\
\text { ent FYM } \\
\text { M - Poult } \\
\text { ecompose }\end{array}$ & anting & $\begin{array}{l}\text { M - M } \\
- \text { Decc }\end{array}$ & $\begin{array}{l}\text { s } \\
\text { sers } \\
\text { nure }\end{array}$ & \\
\hline
\end{tabular}


The infiltration capacity is said to increase upto $130 \mathrm{~mm} \mathrm{hr}^{-1}$ against $10 \mathrm{~mm} \mathrm{hr}^{-1}$ of a conventional farm. This ensures ground water retention and prevents soil erosion.

The subsequent decomposition of these materials might have resulted in enhanced organic carbon content of soil which resulted in increased water holding capacity and reduced bulk density due to humic substances penetrated the inter lamella space of clay minerals and influenced the interaction of clay with other soil constituents and ultimately increased water holding capacity of the soil (Singh et al., 2006). An organic farming system trial conducted for 30 years at Rodale Institute, USA, involving organic compost equivalent to $190 \mathrm{~kg} \mathrm{~N} \mathrm{ha}^{-1}$ for maize and 120 $\mathrm{kg} \mathrm{ha}^{-1}$ for oats was applied and then rotated with legumes like soybean and alfalfa. Results clearly revealed that soil aggregation, water holding capacity, soil aeration were improved. The results of the present study are in accordance with Bhawalkar (1993) and Lanchnicht et al., (1997). They reported that apart from raising the water table, the earthworm act as bio-pump by transporting moisture from lower layers to upper ones and increased macro pore formation due to earthworm burrows, which could increase preferential flow pathways, and movement of $\mathrm{N}$ through the soil profile.

Green chilli yield varied significantly due to application of different sources of FYM, vermicompost, poultry manure and sheep manure during Kharif, 2017 and 2018 seasons. Significantly higher green chilli yield (20.47 and $23.09 \mathrm{t} \mathrm{ha}^{-1}$ ) was recorded with the application of vermicompost at 100 per cent $\mathrm{N}$ equivalent and it was 10.74 and 11.04 per cent higher yield over the application of 100 per cent $\mathrm{N}$ equivalent through FYM. Whereas, the application of vermicompost recorded 5.23 and 5.37 per cent higher yield over the 100 per cent $\mathrm{N}$ equivalent through poultry manure
(Table 1). Application of poultry manure recorded 5.82 and 5.99 per cent higher through FYM during both the seasons. These results are in conformity with findings of Husain et al., (2014), Anand and Gupta (2018), Chandansingh and Azad husain (2015), Adekiya et al., (2017). Lesser yield was observed with poultry manure, sheep manure and FYM might be due to higher $\mathrm{C}: \mathrm{N}$ ratio which lead to less mineralization of nutrients in the soil as a result there will be less amount of available nutrient by the crop during growing season and in addition to this cumulative volatilization losses of $\mathrm{NH}_{3}-\mathrm{N}$ during aerobic and anaerobic composting of poultry manure, sheep manure and FYM and there were only traces amount of $\mathrm{NO}_{3}{ }^{-}-\mathrm{N}$ is available in these fresh manure which can be taken up by major crop for their metabolic activity (Stevan et al., 1989). According to Anand and Gupta (2018), application of vermicompost increased the weight of fruits, number of fruits, stem diameter and dry matter yield of radish as compare to the application of cow dung where it recorded less weight of fruits, number of fruits, stem diameter and dry matter yield of radish. The increase in chilli yield might be due to significant increase in yield parameters such as higher number of fruits, fruit length and fruit weight during 2017 and 2018.

\section{References}

Adekiya, A. O., T. M., Agbede, Aboyeji, C. M., Dunsin, O. and Ugbe, J. O., 2017, Green manures and NPK fertilizer effects on soil properties, growth, yield, mineral and vitamin $\mathrm{C}$ composition of okra (Abelmoschus esculentus). Bioferti. Soil, 2(1): 1-5.

Ananda, K. and Gupta, R. K., 2018, The effects of vermicompost on growth and yield parameters of vegetable crop radish (Raphanus sativus). J. Pharmaco. Phytoche., 7(2): 589-592.

Arshad, M. A., and Coen. G. M, 1992, 
Characterization of soil quality: Physical and chemical criteria. Amer. J. Alter. Agric. 7:25-31.

Arshad, M. A., Lowery, B. and Grossman, B., 1996. Physical tests for monitoring soil quality. Pp.123-141.

Bhawalkar, V. U., 1993, The living soil. In: Extended Abstracts of congress on Traditional Science and Technologies of India, 28th November-3rd December Bombay. pp. 105-108.

Chandan Singh, A. and Azad Hussain, 2015, Effect of vermicompost on growth, yield and quality of vegetable crops. Int. J. Appl. Pure Sci, Agric., 8 (1): 50-56.

Daundkar, K. S. and Bairagi, S. K., 2015, Economics of production of capsicum in Akola district. Inter. J. Commerce, Business Manage.,8: 81-83.

Eilin, W. and Kevin, P. M., 2012, The influence of added organic matter on soil physical, chemical, and biological properties: a small-scale and short-time experiment using straw. Agron. Soil Sci., 58: (1).

Hangarge, D. S., Raut, R. S., More, S. D., Birajdar, R. R. and Pholane, L. P., 2004, Effect of vermicompost and soil conditioner on some physical properties of soil under chilli-spinach system. $J$. Soils Crops, 12 (1): 41-45

Hussain, S. I., Khakar, K. M., Amanullah, J. and Farroq, M., 2014, Effect of various mulches and soil amendments on germination, growth and fresh rhizomes yield of ginger. Sarhad J. Agric., 17 (1): 87-89.

Kale, R. D., Mallesh, b. c., Bano, K. and Bagyaraj, D. T., 1992, Influence of vermicompost application on available micro nutrients and selected microbial population in a paddy field. Soil Biol. Bioch., 24 (12): 1312-1320.

Lachnicht, S. L., Lavelle, P. and Martin, 1997, Soil Biol. Biochem., 29: 493-498.

Lee, K. E., 1985, Earthworms, their Ecology and Relationships with Land Use. Academic Press, Sydney, pp. 411.
Lowery, B., W.J. Hickey, M.A. Arshad, and R. Lal. 1996. Soil water parameters and soil quality.

Martin, M., 1991, Effect of organic manures on growth, rhizome yield and quality attributes of turmeric (Curcuma longa L.). The Agriculturists, 10 (1): 16-22.

Nelson, D.W., and Sommers. L.E., 1996. Total carbon, organic carbon, and organic matter. p. 961-1010.

Patel, V. K., 2017, An economic analysis of production and marketing of chilli (Capsicum annuum L.) in Raigarh district of Chhattisgarh. M.Sc. thesis submitted to the Department of Agricultural Economics, College of Agriculture, Raipur, India.

Rose, J. and Wood, Y. B. 1980, Effect of forest floor characteristics on water repellency, infiltration, runoff and soil loss in Andisols of Tenerife (Canary Islands, Spain) Catena, 108: 50-57.

Singh, P. P., Yadav, P. K., Singh, R. K., Singh, S. and Singh, J., 2006, Effect of chemical fertilizer, FYM and biofertilizer on performance of rice and soil properties. Crop Res., 32: 283-285.

Spain, A. 1990. Influence of environmental conditions and some soil chemical properties on the carbon and nitrogen contents of some tropical Australian rain-forest soils. Aust. J. Soil Sci. Res. 28:825-839.

Stevan, R. J., Laughline, R. L. and Malone, J. P., 1989, Soil $\mathrm{pH}$ affect the process of reducing nitrate to nitrous oxide and dinitrogen. Soil Boil. Biochemist.,30: 1119-1126.

Stott, D. E., and J. P. Martin, 1989. Organic matter decomposition and retention in arid soils. Arid Soil Res. Rehabil. 3: 115-148.

Velayutham, L. K. and Damodaran. K., 2015, An economic analysis of chillies production in Guntur district of Andhra Pradesh. Inter. J. Res. Econ. Social Sci., 5: 43-49. 


\section{How to cite this article:}

Karale Gangadhar, N. Devakumar, P. K. Basavaraja, K. Murali and Boraiah, B. 2019. Effect of Different Sources of Organic Manures and Decomposers on Physico-Chemical Properties of Soil under Chilli Cultivation. Int.J.Curr.Microbiol.App.Sci. 8(12): 838-850. doi: https://doi.org/10.20546/ijcmas.2019.812.108 